\title{
Comparison of Initial Risk Stratification Methods in Predicting Treatment Outcome in Differentiated Thyroid Cancer
}

\author{
KM Wong, SI Soong, RMW Yeung \\ Department of Clinical Oncology, Pamela Youde Nethersole Eastern Hospital, Hong Kong
}

\begin{abstract}
Introduction: Differentiated thyroid cancer (DTC) is the commonest endocrine malignancy. With accurate risk stratification, low-risk patients can be treated with less intensive treatment and follow-up. We reviewed outcomes of DTC in our hospital and evaluated different staging methods in predicting survival.

Methods: This was a retrospective review including 321 patients with DTC treated in our hospital from 1994 to 2005. The cases were assessed for risk of recurrence using different risk stratification methods available at the time. Disease-free survival (DFS) and overall survival (OS) of each method were analysed by comparing their KaplanMeier plots with log rank tests. The Harrell C-index was used to evaluate the discriminative ability of different risk stratification methods in identifying low- or high-risk cases.

Results: The 10-year DFS and OS were 90.9\% and 93\%, respectively. Comparing the C-indices, the European Organisation for Research and Treatment of Cancer (EORTC) had the highest discriminative power for predicting recurrence $(C$-index $=0.694,95 \%$ confidence interval $[C I]=0.599-0.79)$ and $O S(C$-index $=0.825,95 \% C I=$ 0.725-0.924). The MD Anderson Cancer Center (MDA) came in second for predicting recurrence $(C$-index $=0.669$, $95 \% C I=0.584-0.753)$ and $O S(C$-index $=0.769,95 \% C I=0.690-0.849)$. The commonly used American Joint Committee on Cancer and the International Union Against Cancer/Tumour, Node, Metastasis system (AJCC/UICC $T N M)$ staging ranked third for predicting recurrence $(C$-index $=0.651,95 \% C I=0.561-0.740)$ and $O S(C$-index $=$ $0.747,95 \%$ CI $=0.630-0.863$ ).

Conclusions: All risk stratification methods were reliable tools for initial risk stratification in DTC. We recommend the use of AJCC/UICC TNM or MDA methods for their practicality.
\end{abstract}

Key Words: Disease-free survival; Mortality; Prognosis; Risk factors; Thyroid neoplasms

\footnotetext{
Correspondence: Dr KM Wong, Department of Clinical Oncology, Pamela Youde Nethersole Eastern Hospital, Hong Kong
} Email:ka.ming.iris@gmail.com

Submitted: 22 Aug 2020; Accepted: 7 Dec 2020

Contributors: All authors designed the study. KMW and SIS acquired the data, analysed the data, and drafted the manuscript. All authors critically revised the manuscript for important intellectual content. All authors had full access to the data, contributed to the study, approved the final version for publication, and take responsibility for its accuracy and integrity.

Conflicts of Interest: All authors have disclosed no conflicts of interest.

Funding/Support: This research received no specific grant from any funding agency in the public, commercial, or not-for-profit sectors.

Ethics approval: The study was approved by Hong Kong East Cluster Research Ethics Committee (Ref HKEC-2016-020). The patients were treated in accordance with the tenets of the Declaration of Helsinki. The patients provided written informed consent for all treatments and procedures. 


\title{
中文摘要
}

\section{比較初步風險分層方法預測分化型甲狀腺癌的治療結果}

\author{
黃嘉明、宋崧、楊美雲 \\ 引言 : 分化型甲狀腺癌 (DTC) 是最常見的內分泌惡性腫瘤。準確的風險分層可以對低危患者進行 \\ 較低強化治療和隨訪。我們回顧DTC的治療結果並評估以不同癌症分期預測存活率。 \\ 方法 : 這項回顧性研究納入1994年至2005年在我院接受治療的321例DTC患者。使用當時可用的不同 \\ 風險分層方法對這些病例的復發風險進行評估。通過比較其Kaplan-Meier生存分析和對數秩檢驗來 \\ 分析每種方法的無病存活期（DFS）和總存活期（OS）。Harrell-C指數用於評估在識別低風險或高 \\ 風險病例中不同風險分層方法的判別能力。 \\ 結果：10年無病存活率和總存活率分別為 $90.9 \%$ 和 $93 \%$ 。與 $\mathrm{C}$ 指數相比, 歐洲癌症研究與 \\ 治療組織 $($ EORTC $)$ 在預測復發率 $(C$ 指數 $=0.694,95 \%$ 置信區間 $=0.599-0.79)$ 和總存活率 \\ $(\mathrm{C}$ 指數 $=0.825,95 \%$ 置信區間 $=0.725-0.924)$ 的鑑別力最高 ; 其次為MD Anderson系統MDA \\ （預測復發率：C指數 $=0.669 ， 95 \%$ 置信區間 $=0.584-0.753$; 預測總存活率 : C指數 $=0.769$, \\ $95 \%$ 置信區間 $=0.690-0.849 ）$, 以及常用的美國癌症聯合委員會和國際抗癌聯盟的TNM分期系統 \\ AJCC/UICC TNM（預測復發率：C指數 $=0.651 ， 95 \%$ 置信區間 $=0.561-0.740$; 預測總存活率 : \\ $\mathrm{C}$ 指數 $=0.747,95 \%$ 置信區間 $=0.630-0.863$ )。 \\ 結論 : 所有風險分層方法都是DTC中初始風險分層的可靠工具。就實用性而言, 我們建議使用 \\ AJCC/UICC TNM或MDA方法。
}

\section{INTRODUCTION}

Differentiated thyroid cancer (DTC) is the most common endocrine malignancy and consists of papillary and follicular subtypes. ${ }^{1}$ DTC is the fifth most common cancer among women in Hong Kong and statistics have shown that the incidence of DTC was rising in the early 21 st century globally, although studies, many in Asia, have indicated that this is due to more screening, and not due to an actual increase in disease rates. ${ }^{2,3}$

Treatments for DTC commonly consist of surgical excision, radioactive iodine (RAI) ablation, and thyroxine suppressive therapy, as well as radiotherapy in some cases of metastatic disease. For some patients with small tumours $<1 \mathrm{~cm}$ without lymph node involvement or highrisk factors, active surveillance with ultrasonography may also be considered. ${ }^{4}$ With adequate treatment, patients with early stages of DTC usually have excellent overall survival (OS) with 5-year OS of approximately $\geq 95 \%$. Patients presenting in stage III or IV may have 5-year OS of $40 \% .^{5}$ Therefore, patients with low-risk disease may be given less intensive treatment and follow-up so as to minimise their exposure to radiation and medication. It is therefore important to have good risk stratification methods to assist oncologists in risk stratification of patients to allow formulation of an appropriate treatment and follow-up plan.

In the past, several oncology centres or collaborations across the globe devised risk stratification methods for DTC. These include the American Joint Committee on Cancer and the International Union Against Cancer (AJCC/UICC), the Mayo Clinic, European Organisation for Research and Treatment of Cancer (EORTC) Thyroid Cancer Cooperative Group, the Memorial Sloan Kettering (MSK) Cancer Center, the National Thyroid Cancer Treatment Cooperative Study (NTCTCS) and the MD Anderson Cancer Center (MDA). Given the numerous risk stratification methods available and their being mainly drawn from an overseas population, local data and analysis will further aid clinicians to make clinical decisions in local settings.

With increasing prevalence of DTC due to increased screening, clinicians are anticipating a higher number of patients with DTC in their clinics. Therefore, apart 
from the clinical applicability of each risk stratification method, their practicality and reproducibility are also essential factors for consideration of use in day-today clinical practice. Some risk stratification methods have included many clinicopathological factors for categorisation while others have complicated scoring systems, making them difficult to be adopted widely in daily clinical practice.

In the present study, we aimed to review the treatment outcome of DTC in our hospital and to evaluate the efficacy, practicality, and applicability of different risk stratification methods in a local setting.

\section{METHODS \\ Study Design}

This was a retrospective review of patients diagnosed with DTC and treated and followed up in the Department of Clinical Oncology of Pamela Youde Nethersole Eastern Hospital from 1 January 1994 to 31 December 2005. Our study protocol was approved by the Hong Kong East Cluster Ethics Committee and conducted in accordance with the Declaration of Helsinki. Patient consent was not required as it was a retrospective study based on historical clinical records.

In our centre, a department protocol on management of DTC is available for all doctors as a reference. In general, patients with DTC were considered for adjuvant RAI if they had undergone total thyroidectomy, unless they had very low-risk disease with a favourable disease profile. Otherwise, a RAI dosage of approximately 1100 to $3700 \mathrm{MBq}$ was recommended for patients, depending on their risk profile, such as tumour size and presence of lymph node involvement. After ingestion of RAI, patients would have whole-body scans within 1 week and a repeat scan approximately 6 months later. Patients were started on a thyroid-stimulating hormone-suppressive dose of thyroxine unless contra-indicated, with dosage adjusted later based on treatment response. If patients continued to have RAI-avid residual disease on follow-up scans, RAI was repeated. External beam radiotherapy of up to 70 Gy over 35 fractions was considered for patients with structural residual disease not amendable to further surgery. ${ }^{4}$

\section{Data Sources}

Patient hospital records with primary diagnosis of 'thyroid cancer' during the above stated period were retrieved from the Clinical Data Analysis and Reporting System. Records including consultation notes, operative records, pathology reports, imaging reports including ultrasonography and radioiodine scans, and blood results were reviewed.

A MEDLINE search on DTC, staging and risk stratification methods was done and found 17 documented risk stratification methods. They include the AJCC/UICC Tumor-Node-Metastasis system (AJCC/ UICC TNM) 7th edition, EORTC classification, ${ }^{6}$ the Metastases, Age, Completeness of surgery, Invasion and Size system (MACIS), ${ }^{7}$ the Age, Grade, Extent and Size classification (AGES), ${ }^{8}$ the Age, Metastases, Extent and Size system (AMES), ${ }^{9}$ the MSKCC Grade, Age, Metastases, Extent and Size classification (MSKCC GAMES) ${ }^{10}$ the MDA, ${ }^{11}$ the Clinical Class system (Clinical Class), ${ }^{12}$ the University of Münster system (Münster), ${ }^{13}$ the NTCTCS classification,,${ }^{14}$ the Ohio State University system (OSU), ${ }^{15}$ the Noguchi classification (Noguchi), ${ }^{16}$ the University of Murcia system (Murcia), ${ }^{17}$ the Cancer Institute Hospital system (CIH) ${ }^{18}$ the Ankara Oncology Training and Research Hospital system (Ankara), ${ }^{19}$ the Sex, Age and Grade system (SAG), ${ }^{20}$ and the DNA, Age, Metastases, Extent and Size system (DAMES). ${ }^{21}$

Of the 17 risk stratification systems, only nine could be applied to our patients based on the patient data available. The methods excluded and the various reasons accountable for exclusion are: AGES (lack of tumour grading data), OSU (lack of data on number of intrathyroidal foci), SAG (lack of microscopic description of nuclear atypia), NTCTCS (lack of tumour grading data), CIH (lack of data on size of lymph nodes), Ankara (lack of angioinvasion data), Murcia (lack of histological subtype data), and DAMES (lack of DNA ploidy data).

The calculations or categories used in the nine risk stratification methods analysed in our study are summarised in Table 1. Disease-free survival (DFS) and OS were evaluated. DFS was defined as the date of diagnosis to the date of relapse of DTC or death. OS was defined as the date of diagnosis to the date of death from any cause.

\section{Statistical Methods}

DFS and OS of each risk classification system were analysed by comparing their Kaplan-Meier plots with $\log$ rank test. The Harrell's C-index was used to evaluate the discriminative ability of different risk stratification methods in identifying low- or high-risk patients. A 
Table 1. Calculation and categorisation of risk stratification methods analysed.

\begin{tabular}{|c|c|c|}
\hline $\begin{array}{l}\text { Risk stratification } \\
\text { method }\end{array}$ & Classification or calculation & Scoring \\
\hline $\begin{array}{l}\text { AJCC/UICC TNM } \\
\text { 7th edition }\end{array}$ & $\begin{array}{l}\text { T1 Tumour size } \leq 2 \mathrm{~cm} \text {, limited to thyroid } \\
\text { T2 Tumour }>2-4 \mathrm{~cm} \text {, limited to thyroid } \\
\text { T3 Tumour }>4 \mathrm{~cm} \text { limited to thyroid or any tumour with minimal extrathyroid extension } \\
\text { T4a Tumour of any size extending beyond the thyroid capsule to invade subcutaneous } \\
\text { soft tissues, larynx, trachea, oesophagus or recurrent laryngeal nerve } \\
\text { T4b Tumour invades prevertebral fascia or encases carotid artery or mediastinal vessels } \\
\text { N0 No regional lymph node metastase } \\
\text { N1a Nodal metastases to Level VI lymph nodes } \\
\text { N1b Metastases to unilateral, bilateral or contralateral cervical (Levels I, II, III, IV, V) or } \\
\text { retropharyngeal or superior mediastinal lymph nodes } \\
\text { M1 Distant metastasi }\end{array}$ & $\begin{array}{l}\text { Age }<45 \text { y } \\
\text { Stage I: Any T, any N, MO } \\
\text { Stage II: Any T, any N, M1 } \\
\text { Age } \geq 45 \text { y } \\
\text { Stage I: T1, NO, MO } \\
\text { Stage II: T2, NO, MO } \\
\text { Stage III: T3, NO, MO or } \\
\text { T1-3, N1a, MO } \\
\text { Stage IV: T4 or N1b or M1 }\end{array}$ \\
\hline EORTC & $\begin{array}{l}\text { Total score }=\text { age }+12 \text { (if male) }+10 \text { (if poorly differentiated follicular histology) }+10 \text { (if } \\
\text { thyroid capsule invasion) }+15 \text { (if one distant metastasis) }+30 \text { (if } \geq 2 \text { distant metastases) }\end{array}$ & $\begin{array}{l}\text { Group 1: }<50 \\
\text { Group 2: } 50-65 \\
\text { Group 3: } 66-83 \\
\text { Group 4: } 84-108 \\
\text { Group 5: } \geq 109\end{array}$ \\
\hline MACIS & $\begin{array}{l}\text { Total score }=3.1 \text { (if age } \leq 39 \text { y) or } 0.08 \times \text { age (if age } \geq 40 \text { y) }+0.3 \times \text { tumour size in } \mathrm{cm}+1 \\
\text { (if not completely resected) }+1 \text { (if locally invasive) }+3 \text { (if distant metastasis) }\end{array}$ & $\begin{array}{l}\text { Group 1: }<6.0 \\
\text { Group 2: } 6.0-6.99 \\
\text { Group 3: } 7.0-7.99 \\
\text { Group 4: } \geq 8.0\end{array}$ \\
\hline MDA & $\begin{array}{l}\text { Age }<50 \text { y without distant metastasis; and tumour size }<3 \mathrm{~cm} \\
\text { Age }<50 \text { y without distant metastasis; and tumour size } \geq 3 \mathrm{~cm} \\
\text { Age } \geq 50 \text { y without distant metastasis; and tumour size }<3 \mathrm{~cm} \\
\text { Age } \geq 50 \text { y without distant metastasis; and tumour size } \geq 3 \mathrm{~cm} \\
\text { Any age with distant metastases; and tumour size }<3 \mathrm{~cm} \\
\text { Any age with distant metastases; and tumour size } \geq 3 \mathrm{~cm}\end{array}$ & $\begin{array}{l}\text { Low risk } \\
\text { Intermediate risk } \\
\text { High risk }\end{array}$ \\
\hline MSKCC GAMES & $\begin{array}{l}\text { Age }<45 \mathrm{y} \text {, no distant metastasis, tumour size }<4 \mathrm{~cm} \text { and papillary histology } \\
\text { Age }<45 \mathrm{y} \text {, presence of distant metastasis, tumour size } \geq 4 \mathrm{~cm} \text { or follicular histology or } \\
\text { Age } \geq 45 \mathrm{y} \text {, no distant metastasis, tumour size }<4 \mathrm{~cm} \text { and papillary histology } \\
\text { Age } \geq 45 \mathrm{y} \text {, presence of distant metastasis, tumour }>4 \mathrm{~cm} \text { or follicular histology }\end{array}$ & $\begin{array}{l}\text { Low risk } \\
\text { Intermediate risk } \\
\text { High risk }\end{array}$ \\
\hline Noguchi & $\begin{array}{l}\text { All male age } \leq 45 \text { y or } \\
\text { Male age } \leq 60 \text { y and no gross lymph node metastasis or } \\
\text { Female age } \leq 50 \text { y or } \\
\text { Female age } 50-55 \text { y and no gross lymph node metastasis } \\
\text { Male age }>60 \text { y and no gross lymph node metastasis or } \\
\text { Male age } 46-55 \text { y with gross lymph node metastasis or } \\
\text { Female age } 56-65 \text { y and no gross lymph node metastasis or } \\
\text { Female age }>65 \text { y and tumour size }<3 \text { cm or } \\
\text { Female age } 50-55 \text { y with gross lymph node metastasis } \\
\text { Male age }>55 \text { y with gross lymph node metastasis or } \\
\text { Female not included in the other } 2 \text { risk groups }\end{array}$ & Intermediate risk \\
\hline AMES & $\begin{array}{l}\text { Male age }<41 \text { y without distant metastasis or } \\
\text { Female age }<51 \text { y without distant metastasis or } \\
\text { Male age } \geq 41 \text { y or female age } \geq 51 \text { y with: } \\
\text { Papillary or follicular tumour with minor or no capsular involvement and tumour size } \\
<5 \mathrm{~cm} \text { and no distant metastasis } \\
\text { Any distant metastasis or } \\
\text { Male age } \geq 41 \text { y or female age } \geq 51 \text { y with: } \\
\text { Papillary or follicular with major capsular involvement or tumour size } \geq 5 \mathrm{~cm}\end{array}$ & Low risk \\
\hline Clinical Class & $\begin{array}{l}\text { Disease limited to thyroid gland } \\
\text { Presence of locoregional lymph node involvement } \\
\text { Presence of extrathyroidal tumour invasion } \\
\text { Presence of distant metastases }\end{array}$ & $\begin{array}{l}\text { Class I } \\
\text { Class II } \\
\text { Class III } \\
\text { Class IV }\end{array}$ \\
\hline Münster & $\begin{array}{l}\text { Disease limited to thyroid gland without distant metastasis } \\
\text { Presence of extrathyroidal tumour invasion or distant metastasis }\end{array}$ & $\begin{array}{l}\text { Low risk } \\
\text { High risk }\end{array}$ \\
\hline
\end{tabular}

Abbreviations: AJCC/UICC TNM = American Joint Committee on Cancer and the International Union Against Cancer Tumor-Node-Metastasis system; AMES = Age, Metastases, Extent and Size system; EORTC = European Organisation for Research and Treatment of Cancer; MACIS = Metastases, Age, Completeness of surgery, Invasion and Size system; MSKCC GAMES = Memorial Sloan Kettering Cancer Center Grade, Age, Metastases, Extent and Size classification; MDA = MD Anderson Cancer Center. 
C-index of 1 implies that the risk stratification method can perfectly select individuals with discordant events, while a $\mathrm{C}$-index of 0.5 shows that the risk stratification method fails to show any discriminative ability. C-index of $>0.65$ is considered an acceptable model for predicting outcome. Statistical analysis was performed using SPSS (Window version 22.0; IBM Corp, Armonk [NY], United States) and R statistical software version 3.3.3.

\section{RESULTS}

A total of 321 patients were included in our study. The median follow-up time was 143.3 months (range, $0.3-461.7)$. The percentage of patients with $<1$ year of follow-up was $2.49 \%$.

\section{Demographics}

Demographic distribution of our study population is tabulated in Table 2. Females accounted for $81.3 \%$ of the study population with median age 46 years. A total of $79.4 \%$ of patients presented with thyroid nodules and only $4 \%$ of patients reported symptoms of thyrotoxicosis. Papillary carcinoma and follicular carcinoma accounted for $91.6 \%$ and $8.4 \%$ of the study cohort, respectively. About one-third (34\%) of our patients had multifocal disease confirmed on histological examination.

\section{Operative and Postoperative Treatment}

A total of $94.4 \%$ of patients underwent total thyroidectomy with $29.9 \%$ patients receiving planned selective neck dissection according to the preoperative lymph node status. Proportions of patients achieving $\mathrm{R} 0, \mathrm{R} 1$ and $\mathrm{R} 2$ resections were $76 \%, 15 \%$, and $2.2 \%$, respectively. Most of the patients $(91.6 \%)$ received at least one dose of RAI. For the first postoperative RAI, the most commonly used dose was $80 \mathrm{mCi}(93.9 \%)$ according to our department protocol. On the first postablation whole-body scan, $58.5 \%$ of patients showed uptake over the thyroid bed only. On the subsequent follow-up whole-body scan 6 months after RAI, 67.3\% of patients showed no significant uptake in the entire body. Of the patients receiving postoperative RAI, $27.9 \%$ proceeded to receive a second-dose RAI while $8.9 \%$ further received a third RAI. Only about 5\% received postoperative external beam radiotherapy with a median dose of 60 Gy (range, 50-64).

\section{Survival Analysis}

In our study, the 10-year and 15-year OS were $93 \%$ and $88.2 \%$, respectively. The 10-year and 15-year DFS were
Table 2. Demographic and background data of the study population $(n=321)$.

\begin{tabular}{|c|c|}
\hline & $\begin{array}{c}\text { No. (\%) of } \\
\text { patients }\end{array}$ \\
\hline \multicolumn{2}{|l|}{ Sex } \\
\hline Male & $60(18.7 \%)$ \\
\hline Female & $261(81.3 \%)$ \\
\hline Age median (range) & $46(12-83)$ \\
\hline \multicolumn{2}{|l|}{ Initial presentation } \\
\hline Thyroid nodule & 255 (79.4\%) \\
\hline Diffuse thyroid swelling & $29(9.0 \%)$ \\
\hline Incidental finding on imaging & $8(2.5 \%)$ \\
\hline Others/unknown & $29(9.0 \%)$ \\
\hline \multicolumn{2}{|l|}{ Thyroid functional status } \\
\hline Hyperthyroidism & $13(4.0 \%)$ \\
\hline \multicolumn{2}{|l|}{ Surgical treatment (thyroid) } \\
\hline Total thyroidectomy & $303(94.4 \%)$ \\
\hline Subtotal thyroidectomy & $17(5.3 \%)$ \\
\hline Unknown & $1(0.3 \%)$ \\
\hline \multicolumn{2}{|c|}{ Surgical treatment (cervical lymph nodes) $[n=96]$} \\
\hline Central neck dissection & $40(41.7 \%)$ \\
\hline Unilateral neck dissection & $47(49.0 \%)$ \\
\hline Bilateral neck dissection & $9(9.4 \%)$ \\
\hline \multicolumn{2}{|l|}{ Resection clearance } \\
\hline Clear margin & $244(76.0 \%)$ \\
\hline Microscopic residual & $48(15.0 \%)$ \\
\hline Gross residual & $7(2.2 \%)$ \\
\hline Unknown & $22(6.9 \%)$ \\
\hline \multicolumn{2}{|l|}{ Histology } \\
\hline Papillary & $294(91.6 \%)$ \\
\hline Follicular & $27(8.4 \%)$ \\
\hline \multicolumn{2}{|l|}{ Multifocality } \\
\hline Solitary tumour & $198(61.7 \%)$ \\
\hline Multifocal tumour & $109(34.0 \%)$ \\
\hline Unknown & $4(1.2 \%)$ \\
\hline \multicolumn{2}{|c|}{ AJCC/UICC TNM 7th edition staging } \\
\hline I & $243(75.7 \%)$ \\
\hline$\|$ & $48(15.0 \%)$ \\
\hline III & $7(2.2 \%)$ \\
\hline IVA & 22 (6.9\%) \\
\hline IVB & $1(0.3 \%)$ \\
\hline \multicolumn{2}{|l|}{ Postoperative radioactive iodine } \\
\hline Yes & $294(91.6 \%)$ \\
\hline No & 27 (8.4\%) \\
\hline \multicolumn{2}{|l|}{ Postoperative radiotherapy } \\
\hline Yes & $16(5.0 \%)$ \\
\hline No & $305(95.0 \%)$ \\
\hline
\end{tabular}

Abbreviation: AJCC/UICC TNM = American Joint Committee on Cancer and the International Union Against Cancer Tumor-NodeMetastasis system.

$90.9 \%$ and $77 \%$, respectively. The DFS Kaplan-Meier curves for risk stratification methods with C-index of $\geq 0.65$ are shown in Figure 1. The OS Kaplan-Meier curves for risk stratification methods with C-index of $\geq 0.65$ are shown in Figure 2 .

\section{Comparison of Risk Stratification Methods}

Distribution of patients in the different risk stratification 


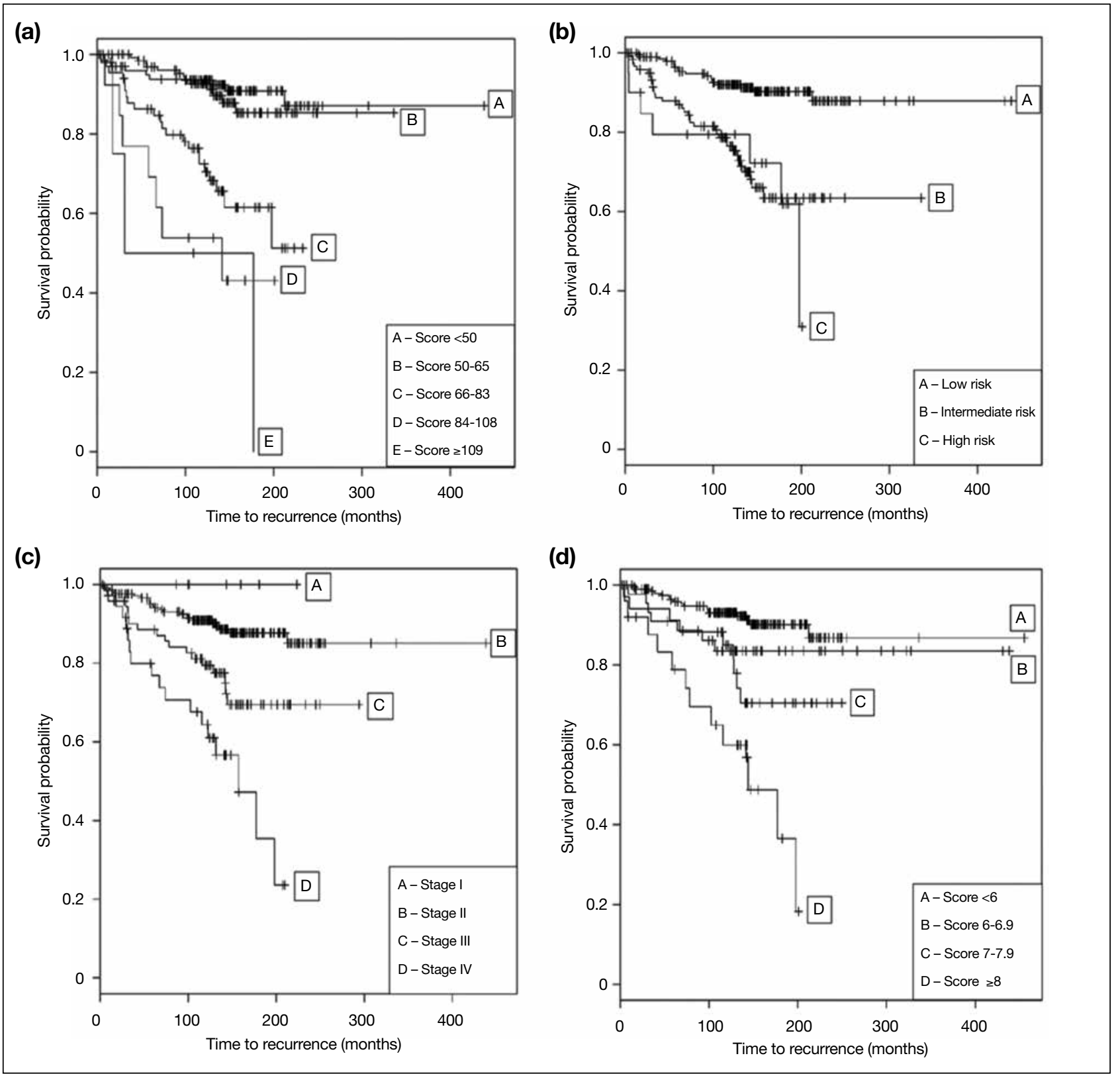

Figure 1. Disease-free survival curves by the (a) EROTC, (b) MDA, (c) AJCC/UICC TNM, and (d) MACIS risk stratification methods.

Abbreviations: AJCC/UICC TNM = American Joint Committee on Cancer and the International Union Against Cancer Tumor-Node-Metastasis system; EORTC = European Organisation for Research and Treatment of Cancer; GAMES = Grade, Age, Metastases, Extent and Size classification; MACIS = Metastases, Age, Completeness of surgery, Invasion and Size system; MDA = MD Anderson Cancer Center.

methods is tabulated in Table 3. Table 4 shows the C-index of the risk stratification methods and their rankings, in terms of DFS and OS, respectively. Comparing the C-indices, EORTC had the highest discriminative power for both predicting recurrence $(\mathrm{C}$-index $=0.694$, 95\% confidence interval $[\mathrm{CI}]=0.599-0.790)$ and OS $(\mathrm{C}$-index $=0.825,95 \% \mathrm{CI}=0.725-0.924)$. MDA came in second in predicting recurrence $(\mathrm{C}$-index $=0.669$, $95 \% \mathrm{CI}=0.584-0.753)$ and OS $(\mathrm{C}$-index $=0.769$, $95 \% \mathrm{CI}=0.690-0.849)$. The AJCC/UICC TNM staging, which we commonly used in our daily practice, ranked third with a C-index of $0.651(95 \% \mathrm{CI}=0.561-0.740)$ for predicting recurrence and C-index of 0.747 $(95 \% \mathrm{CI}=0.630-0.863)$ for predicting OS. 
(a)

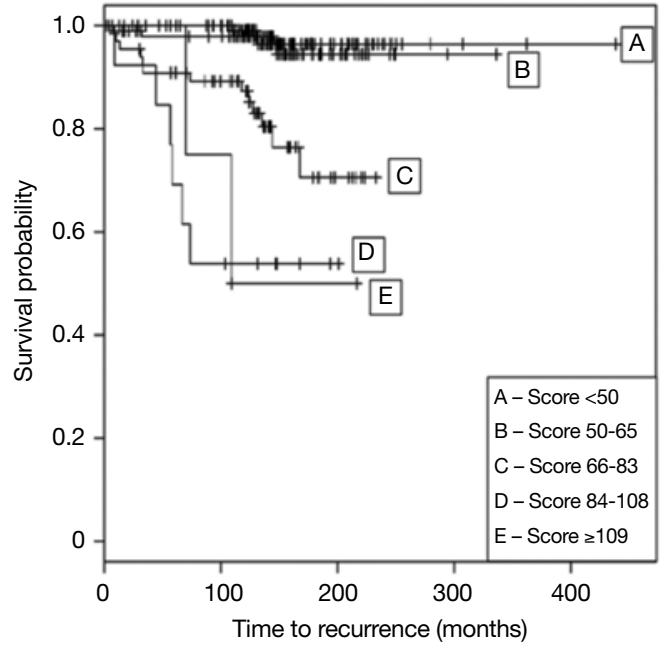

(c)

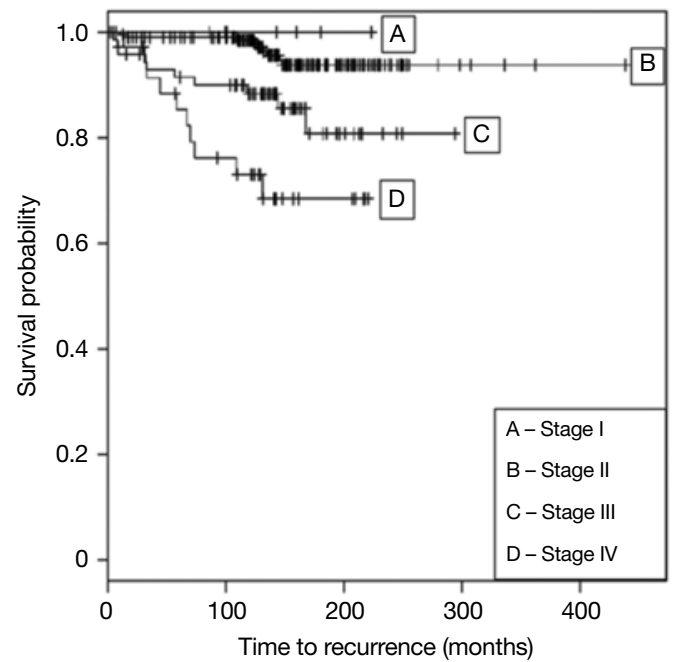

(e)

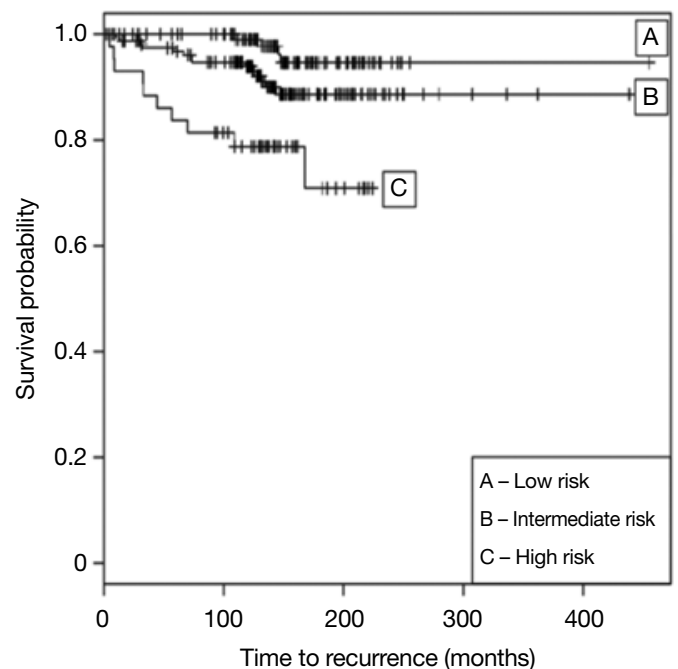

(b)

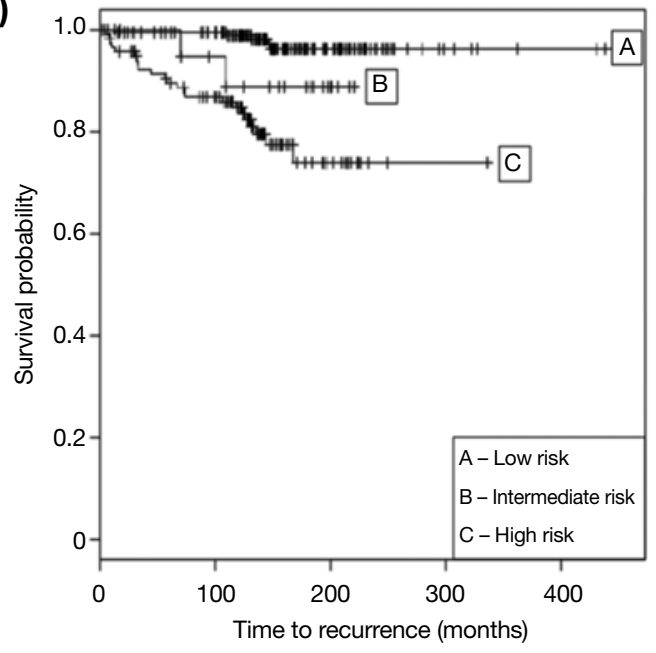

(d)

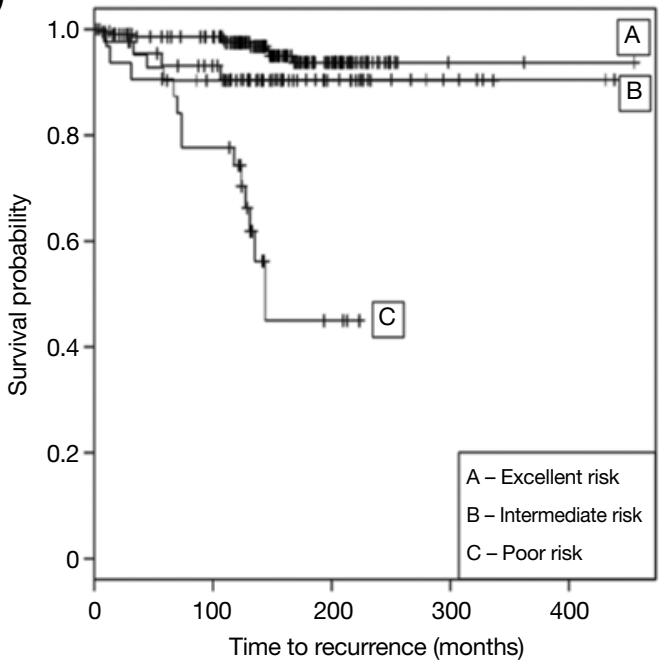

(f)

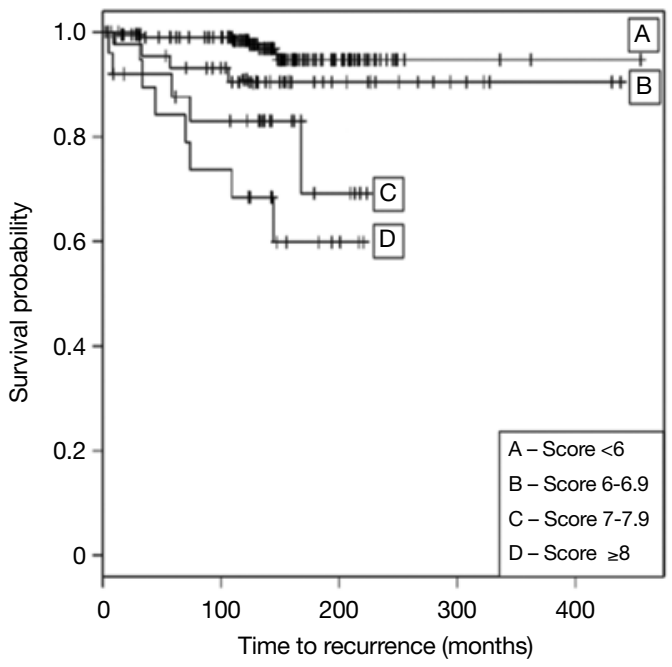

Figure 2. Overall survival curves of (a) EORTC, (b) MDA, (c) AJCC/UICC TNM, (d) Noguchi, (e) MSKCC GAMES, and (f) MACIS risk stratification methods.

Abbreviations: AJCC/UICC TNM = American Joint Committee on Cancer and the International Union Against Cancer Tumor-Node-Metastasis system; EORTC = European Organisation for Research and Treatment of Cancer; MACIS = Metastases, Age, Completeness of surgery, Invasion and Size system; MDA = MD Anderson Cancer Center; MSKCC GAMES = Memorial Sloan Kettering Cancer Center Grade, Age, Metastases, Extent and Size classification. 
Table 3. Patient distribution according to risk stratification methods $(n=321)$.

\begin{tabular}{|c|c|c|}
\hline $\begin{array}{l}\text { Risk stratification } \\
\text { method }\end{array}$ & $\begin{array}{l}\text { Risk stratification } \\
\text { group }\end{array}$ & $\begin{array}{c}\text { No. of patients } \\
(\%)\end{array}$ \\
\hline \multirow[t]{4}{*}{ AJCC/UICC TNM } & Stage I & 162 (50.5\%) \\
\hline & Stage II & $57(17.8 \%)$ \\
\hline & Stage III & 74 (23.1\%) \\
\hline & Stage IV & 28 (8.7\%) \\
\hline \multirow[t]{5}{*}{ EORTC } & Group 1: <50 & 136 (42.4\%) \\
\hline & Group 2: 50-65 & 101 (31.5\%) \\
\hline & Group 3: 66-83 & $66(20.6 \%)$ \\
\hline & Group 4: 84-108 & $14(4.4 \%)$ \\
\hline & Group 5: $\geq 109$ & $4(1.2 \%)$ \\
\hline \multirow{4}{*}{ MACIS $(n=287)$} & Group 1: <6.0 & 206 (71.8\%) \\
\hline & Group 2: 6.0-6.99 & $34(11.8 \%)$ \\
\hline & Group 3: 7.0-7.99 & 27 (9.4\%) \\
\hline & Group 4: $\geq 8.0$ & 20 (7.0\%) \\
\hline \multirow[t]{3}{*}{ MDA } & Low risk & 198 (61.7\%) \\
\hline & Intermediate risk & 103 (32.1\%) \\
\hline & High risk & $20(6.2 \%)$ \\
\hline \multirow[t]{3}{*}{ MSKCC GAMES } & Low risk & 121 (37.7\%) \\
\hline & Intermediate risk & 155 (48.3\%) \\
\hline & High risk & 45 (14.0\%) \\
\hline \multirow{3}{*}{ Noguchi $(n=300)$} & Excellent risk & 220 (73.3\%) \\
\hline & Intermediate risk & 46 (15.3\%) \\
\hline & Poor risk & $34(11.3 \%)$ \\
\hline \multirow[t]{2}{*}{ AMES $(n=279)$} & High risk & 253 (90.7\%) \\
\hline & Low risk & 26 (9.3\%) \\
\hline \multirow[t]{4}{*}{ Clinical Class $(n=296)$} & Class I & 106 (35.8\%) \\
\hline & Class II & $46(15.5 \%)$ \\
\hline & Class III & 126 (42.6\%) \\
\hline & Class IV & $18(6.1 \%)$ \\
\hline \multirow[t]{2}{*}{ Münster $(n=319)$} & Low risk & 154 (48.3\%) \\
\hline & High risk & $165(51.7 \%)$ \\
\hline
\end{tabular}

Abbreviations: AJCC/UICC TNM = American Joint Committee on Cancer and the International Union Against Cancer TumorNode-Metastasis system; AMES = Age, Metastases, Extent and Size system; EORTC = European Organisation for Research and Treatment of Cancer; MACIS = Metastases, Age, Completeness of surgery, Invasion and Size system; MDA = MD Anderson Cancer Center; MSKCC GAMES = Memorial Sloan Kettering Cancer Center Grade, Age, Metastases, Extent and Size classification.

\section{DISCUSSION}

Precise clinicopathological staging is crucial in both patient management and communication in doctorpatient and doctor-doctor settings. A good staging system provides reliable estimation of risk of recurrence and disease-specific mortality for individual patients, hence allowing clinicians to make evidence-based decisions on the aggressiveness of adjuvant treatment, intensity of follow-up, and for patient education and counselling. ${ }^{22}$ Moreover, a widely adopted staging and risk stratification system can also allow clinicians around the globe to communicate effectively, providing a common language for medical discussion and research
Table 4. Harrell's C-indices and ranking of various risk stratification methods for disease-free and overall survivals.

\begin{tabular}{llcc}
\hline Rank & Risk stratification & \multicolumn{2}{c}{ Disease-free survival } \\
\cline { 3 - 4 } & & C-index & $\begin{array}{c}95 \% \text { confidence } \\
\text { interval }\end{array}$ \\
\hline 1 & EORTC & 0.694 & $0.599-0.790$ \\
2 & MDA & 0.669 & $0.584-0.753$ \\
3 & AJCC/UICC TNM & 0.651 & $0.561-0.740$ \\
4 & MACIS & 0.650 & $0.568-0.733$ \\
5 & MSKCC GAMES & 0.630 & $0.533-0.728$ \\
6 & Noguchi & 0.609 & $0.525-0.693$ \\
7 & AMES & 0.600 & $0.525-0.674$ \\
8 & Clinical Class & 0.600 & $0.516-0.683$ \\
9 & Münster & 0.548 & $0.462-0.634$ \\
\hline Rank & Risk stratification & \multicolumn{2}{c}{ Overall survival } \\
\cline { 2 - 4 } & system & C-index & $95 \%$ confidence \\
& & & interval \\
\hline 1 & EORTC & 0.825 & $0.725-0.924$ \\
2 & MDA & 0.769 & $0.690-0.849$ \\
3 & AJCC/UICC TNM & 0.747 & $0.630-0.863$ \\
4 & Noguchi & 0.718 & $0.616-0.819$ \\
5 & MSKCC GAMES & 0.711 & $0.608-0.814$ \\
6 & MACIS & 0.678 & $0.570-0.787$ \\
7 & AMES & 0.594 & $0.490-0.698$ \\
8 & Clinical Class & 0.523 & $0.403-0.644$ \\
9 & Münster & 0.499 & $0.382-0.615$ \\
\hline A & &
\end{tabular}

Abbreviations: AJCC/UICC TNM = American Joint Committee on Cancer and the International Union Against Cancer TumorNode-Metastasis system; AMES = Age, Metastases, Extent and Size system; EORTC = European Organisation for Research and Treatment of Cancer; MACIS = Metastases, Age, Completeness of surgery, Invasion and Size system; MDA = MD Anderson Cancer Center; MSKCC GAMES = Memorial Sloan Kettering Cancer Center Grade, Age, Metastases, Extent and Size classification.

studies. An effective staging system should adequately offer predictability, practicality, and reproducibility in order to serve the multiple purposes mentioned above.

Many systems have been proposed and studied for risk stratification of DTC. Each system employs a slightly different set of clinical and pathological factors. Age and presence of metastases are well-recognised prognostic factors in DTC and hence included in most risk stratification methods. ${ }^{23-26}$ In our study, the EORTC, MDA, and AJCC/UICC TNM methods came in the first three positions in terms of discriminative ability to differentiate low-risk from high-risk population, which is in concordance with previous studies of this topic..$^{27,28}$ This may be accountable by the heavy weighting given to age or the presence of distant metastases in these systems. For instance, in the EORTC calculation, distant 
metastases give the highest contributing score of 15 to 30 depending on the number of metastases. Meanwhile, for AJCC/UICC TNM staging method, all patients aged $<45$ years belong to stage I or II regardless of tumour size, local extent, or nodal involvement. For the MDA method, age and presence of distant metastases are the only consideration factors, eliminating other less influential clinicopathological factors included in other systems.

Direct comparison of the different risk stratification methods can be difficult as each method includes different histologies of DTC. All histologies of thyroid cancer were included in the AJCC/UICC TNM and EORTC systems, while only papillary thyroid cancer is included in the MACIS, Clinical Class, and Noguchi methods. Both papillary and follicular thyroid cancers are included in the MDA, AMES, MSKCC GAMES, and Münster methods. As papillary, follicular, medullary and anaplastic thyroid cancer each has a distinct disease behaviour and prognostic curve, the survival data across two or more histology types are more difficult to be interpreted and compared directly with data from other studies. We recognise that medullary and anaplastic thyroid cancers are rare disease entities, and it is challenging to recruit adequate number of cases for reliable analysis.
Practicality and reproducibility are essential consideration factors in everyday clinical practice. Some risk stratification systems involve a more complicated calculation, allowing different clinicopathological factors to have different weighting on the risk stratification outcome. For instance, EORTC assigns a score to each clinicopathological factor (eg, 12 for male sex, 15 for one distant metastasis) and requires the sum of the scores. Another example is in MACIS, where clinicians need to perform multiplications and summation of various clinicopathological factors (eg, multiplying age by 0.08 for patients aged $\geq 40$ years, multiplying tumour size in $\mathrm{cm}$ by 0.3 ). These may render certain risk stratification methods less convenient to be applied in day-to-day practice. Therefore, in the aspect of practicality, the AJCC/UICC TNM and MDA systems appear more intuitive and clinician-friendly for interpretation and patient counselling. The pros and cons of each risk stratification method with a good discriminative power are listed in Table 5.

Several risk stratification methods have not been included in our study as certain required variables are not routinely available in our pathology reports. Some of these pathological characteristics include size of lymph nodes, nuclear atypias, and DNA ploidy. According to the thyroid cancer structured reporting protocol by

Table 5. Pros and cons of various risk stratification methods.

\begin{tabular}{|c|c|c|}
\hline & Pros & Cons \\
\hline EORTC & $\begin{array}{l}\text { - Strong in OS prognostication } \\
\text { - More outcome groups for more refined risk stratification }\end{array}$ & $\begin{array}{l}\text { - Complicated calculation limiting daily application } \\
\text { - Risk stratification group cut-offs are less intuitive }\end{array}$ \\
\hline MDA & $\begin{array}{l}\text { - Good in OS prognostication } \\
\text { - Simple categorisation } \\
\text { - High reproducibility }\end{array}$ & - Possible over-inclusion into intermediate risk group \\
\hline AJCC/UICC TNM & $\begin{array}{l}\text { - Good in OS prognostication } \\
\text { - More internationally recognised } \\
\text { - Easy communication among clinicians and patients } \\
\text { - More outcome groups for more refined risk stratification }\end{array}$ & $\begin{array}{l}\text { - Requires accurate documentation by or } \\
\text { communication with surgeons, radiologists or } \\
\text { pathologists (eg, extent of invasion, level of lymph } \\
\text { nodes involved) }\end{array}$ \\
\hline Noguchi & $\begin{array}{l}\text { - Good in OS prognostication } \\
\text { - Study based on Asian population } \\
\text { - Relatively simple categorisation } \\
\text { - High reproducibility }\end{array}$ & $\begin{array}{l}\text { - Does not include distant metastasis for risk } \\
\text { stratification which is a recognised prognostic factor }\end{array}$ \\
\hline MSKCC GAMES & $\begin{array}{l}\text { - Good in OS prognostication } \\
\text { - Relatively simple categorisation } \\
\text { - High reproducibility }\end{array}$ & $\begin{array}{l}\text { - Does not include lymph node metastasis for risk } \\
\text { stratification which is a recognised prognostic factor }\end{array}$ \\
\hline MACIS & $\begin{array}{l}\text { - Fair in OS prognostication } \\
\text { - More outcome groups for more refined risk stratification }\end{array}$ & $\begin{array}{l}\text { - Complicated calculation limiting daily application } \\
\text { - Risk stratification group cut-offs are less intuitive }\end{array}$ \\
\hline
\end{tabular}

Abbreviations: AJCC/UICC TNM = American Joint Committee on Cancer and the International Union Against Cancer Tumor-Node-Metastasis system; EORTC = European Organisation for Research and Treatment of Cancer; MACIS = Metastases, Age, Completeness of surgery, Invasion and Size system; MSKCC GAMES = Memorial Sloan Kettering Cancer Center Grade, Age, Metastases, Extent and Size classification; OS = overall survival; MDA = MD Anderson Cancer Center 
the International Collaboration on Cancer Reporting, certain parameters, such as exact number of tumour foci, size of lymph nodes, and tumour grading are not required to be included in the pathology reports. ${ }^{29}$ These parameters have only been reported in limited studies to be correlated with prognostication. A prospective study in collaboration with pathologists will be needed if these parameters are to be investigated in the future.

\section{Limitations}

Limitations in our study include the inherent bias in its retrospective design and the lack of complete pathological data required for all risk stratification methods. The long follow-up time in this study implies that there may have been changes in practice, especially with the emerging utility of thyroglobulin to guide clinical management. In addition, further analysis with the newer version of the AJCC/UICC TNM staging system would elucidate its applicability in our local population.

Building on the basis of initial risk stratification, the role of dynamic risk stratification is also coming to light in the current era. ${ }^{30,31}$ We recognise that initial staging is only the beginning of the risk stratification process. A more tailor-made risk stratification specific to each individual patient will require further clinical information on follow-up, such as postoperative serum thyroglobulin and post-RAI scan findings. ${ }^{31-34}$ With the increasing availability of molecular analysis in the modern era, certain molecular markers such as BRAF or RET may also be factored in for more accurate risk stratification. ${ }^{35,36}$ Therefore, although both AJCC/UICC TNM and MDA can offer a reliable and convenient means for initial risk stratification, we recommend that it should be coupled with the American Thyroid Association risk stratification system and further dynamic risk stratification (based on presence of biochemical or structural evidence of relapse over time) to best estimate an individual patient's survival and risk of recurrence.

\section{CONCLUSION}

AJCC/UICC TNM,EORTC, and MDA risk stratification methods are all reliable tools for initial risk stratification in DTC. We recommend the use of AJCC/UICC TNM staging in daily practice for its practicality and global recognition, in combination with the American Thyroid Association and dynamic risk stratification to best predict individualised risk of recurrence and survival in patients with DTC.

\section{REFERENCES}

1. Figge JJ. Epidemiology of thyroid cancer. In: Wartofsky L, Van Nostrand D, editors. Thyroid Cancer. Washington: Humana Press; 2006: p 9-13.

2. Hong Kong Cancer Registry, Hospital Authority. Thyroid Cancer in 2018. Available from: https://www3.ha.org.hk/cancereg/pdf/ factsheet/2018/thyroid_2018.pdf. Accessed 17 Feb 2021.

3. Powers AE, Marcadis AR, Lee M, Morris LG, Marti JL. Changes in trends in thyroid cancer incidence in the United States, 1992 to 2016. JAMA. 2019;322:2440-1.

4. National Comprehensive Cancer Network Clinical Practice Guidelines in Oncology Thyroid Carcinoma Version 3.2020. https://www.ncen.org/professionals/physician_gls/pdf/thyroid.pdf. Accessed 17 Feb 2021

5. American Joint Committee on Cancer. AJCC Cancer Staging Manual Seventh Edition 2010. Available from: http://cancerstaging. org/references-tools/deskreferences/Documents/AJCC $\% 207$ th $\% 20$ Ed\%20Cancer\%20Staging\%20Manual.pdf. Accessed 1 Aug 2020

6. Byar DP, Green SB, Dor P, Williams ED, Colon J, van Gilse HA, et al. A prognostic index for thyroid carcinoma. A study of the E.O.R.T.C. Thyroid Cancer Cooperative Group. Eur J Cancer. 1979;15:1033-41.

7. Hay ID, Bergstralh EJ, Goellner JR, Ebersold JR, Grant CS Predicting outcome in papillary thyroid carcinoma: development of a reliable prognostic scoring system in a cohort of 1779 patients surgically treated at one institution during 1940 through 1989. Surgery. 1993;114:1050-7

8. Hay ID, Grant CS, Taylor WF, McConahey WM. Ipsilateral lobectomy versus bilateral lobar resection in papillary thyroid carcinoma: a retrospective analysis of surgical outcome using a novel prognostic scoring system. Surgery. 1987;102:1088-95.

9. Cady B, Rossi R. An expanded view of risk-group definition in differentiated thyroid carcinoma. Surgery. 1988;104:947-53.

10. Shaha AR, Loree TR, Shah JP. Intermediate-risk group for differentiated carcinoma of thyroid. Surgery. 1994;116:103640.

11. Beenken S, Roye D, Weiss H, Sellers M, Urist M, Diethelm A, et al. Extent of surgery for intermediate-risk well-differentiated thyroid cancer. Am J Surg. 2000;179:51-6.

12. DeGroot LJ, Kaplan EL, McCormick M, Straus FH. Natural history, treatment, and course of papillary thyroid carcinoma. J Clin Endocrinol Metab. 1990;71:414-24.

13. Lerch H, Schober O, Kuwert T, Saur HB. Survival of differentiated thyroid carcinoma studied in 500 patients. J Clin Oncol. 1997;15:2067-75.

14. Sherman SI, Brierley JD, Sperling M, Ain KB, Bigos ST, Cooper DS, et al. Prospective multicenter study of thyroid carcinoma treatment: initial analysis of staging and outcome. National Thyroid Cancer Treatment Cooperative Study Registry Group. Cancer. 1998;83:1012-21.

15. Mazzaferri EL, Jhiang SM. Long-term impact of initial surgical and medical therapy on papillary and follicular thyroid cancer. Am J Med. 1994;97:418-28.

16. Noguchi S, Murakami N, Kawamoto H. Classification of papillary cancer of the thyroid based on prognosis. World J Surg. 1994;18:552-7.

17. Sebastian SO, Gonzalez JM, Paricio PP, Perez JS, Flores DP, Madrona AP, et al. Papillary thyroid carcinoma: prognostic index for survival including the histological variety. Arch Surg. 2000;135:272-7.

18. Sugitani I, Kasai N, Fujimoto Y, Yanagisawa A. A novel classification system for patients with PTC: addition of the 
new variables of large $(3 \mathrm{~cm}$ or greater) nodal metastases and reclassification during the follow-up period. Surgery. 2004;135:139-48.

19. Yildirim E. A model for predicting outcomes in patients with differentiated thyroid cancer and model performance in comparison with other classification systems. J Am Coll Surg. 2005;200:378-92.

20. Akslen LA. Prognostic importance of histologic grading in papillary thyroid carcinoma. Cancer. 1993;72:2680-5.

21. Pasieka JL, Zedenius J, Auer G, Grimelius L, Höög A, Lundell G, et al. Addition of nuclear DNA content to the AMES risk-group classification for papillary thyroid cancer. Surgery. 1992;112:11549.

22. Tuttle RM, Alzahrani AS. Risk stratification in differentiated thyroid cancer: from detection to final follow-up. J Clin Endocrinol Metab. 2019;104:4087-100.

23. Bischoff LA, Curry J, Ahmed I, Pribitkin E, Miller JL. Is above age 45 appropriate for upstaging well-differentiated papillary thyroid cancer? Endocr Pract. 2013;19:995-7.

24. Ganly I, Nixon IJ, Wang LY, Palmer FL, Migliacci JC, Aniss A, et al. Survival from differentiated thyroid cancer: what has age got to do with it? Thyroid. 2015;25:1106-14.

25. Casara D, Rubello D, Saladini G, Masarotto G, Favero A, Girelli ME, et al. Different features of pulmonary metastases in differentiated thyroid cancer: natural history and multivariate statistical analysis of prognostic variables. J Nucl Med. 1993;34:1626-31.

26. Mazurat A, Torroni A, Hendrickson-Rebizant J, Benning H, Nason RW, Pathak KA. The age factor in survival of a population cohort of well-differentiated thyroid cancer. Endocr Connect. 2013;2:154-60.

27. Lang BH, Lo CY, Chan WF, Lam KY, Wan KY. Staging systems for papillary thyroid carcinoma: a review and comparison. Ann Surg. 2007;245:366-78.
28. Lang BH, Chow SM, Lo CY, Law SC, Lam KY. Staging systems for papillary thyroid carcinoma: a study of 2 tertiary referral centers. Ann Surg. 2007;246:114-21.

29. International Collaboration on Cancer Reporting. Thyroid Cancer Structured Reporting Protocol. 2nd edition. 2020. Available from: https://www.rcpa.edu .au/getattachment/d2f937ce-5025-402b8eb1-84e580f59f8a/Protocol-thyroid-cancer.aspx. Accessed 1 Aug 2020.

30. Tuttle RM,Leboeuf R, Shaha AR. Medical management of thyroid cancer: a risk adapted approach. J Surg Oncol. 2008;97:712-6.

31. Tuttle RM, Tala H, Shah J, Leboeuf R, Ghossein R, Gonen M, et al. Estimating risk of recurrence in differentiated thyroid cancer after total thyroidectomy and radioactive iodine remnant ablation: using response to therapy variables to modify the initial risk estimates predicted by the new American Thyroid Association staging system. Thyroid. 2010;20:1341-9.

32. Giovanella L, Castellana M, Trimboli P. Unstimulated highsensitive thyroglobulin is a powerful prognostic predictor in patients with thyroid cancer. Clin Chem Lab Med. 2019;58:130-7.

33. Malandrino P, Latina A, Marescalco S, Spadaro A, Regalbuto C, Fulco RA, et al. Risk-adapted management of differentiated thyroid cancer assessed by a sensitive measurement of basal serum thyroglobulin. J Clin Endocrinol Metab. 2011;96:1703-9.

34. Heemstra KA, Liu YY, Stokkel M, Kievit J, Corssmit E, Pereira AM, et al. Serum thyroglobulin concentrations predict disease-free remission and death in differentiated thyroid carcinoma. Clin Endocrinol (Oxf). 2007;66:58-64.

35. Papaleontiou M, Haymart MR. New insights in risk stratification of differentiated thyroid cancer. Curr Opin Oncol. 2014;26:1-7.

36. Glikson E, Alon E, Bedrin L, Talmi YP. Prognostic factors in differentiated thyroid cancer revisited. Isr Med Assoc J. 2017;19:114-8 